\title{
Influence of Silicate Structure on the Low Temperature Synthesis of Belite Cement from Different Siliceous Raw Materials
}

\author{
Ma Tantawy \\ Chemistry Department, Faculty of Science, Minia University, Minia, Egypt \\ Email: matantawy75@yahoo.com
}

Received 15 April 2015; accepted 23 May 2015; published 27 May 2015

Copyright (c) 2015 by author and Scientific Research Publishing Inc.

This work is licensed under the Creative Commons Attribution International License (CC BY). http://creativecommons.org/licenses/by/4.0/

\section{(c) (i) Open Access}

\section{Abstract}

This paper studies the low temperature synthesis of $\beta-\mathrm{C}_{2} \mathrm{~S}$ from mixture of lime, $\mathrm{BaCl}_{2}$ and siliceous raw material (white sand, metakaolin and dealuminated kaolin) with the ratio $(\mathrm{Ca}+\mathrm{Ba}) / \mathrm{Si}$ $=2$. The Mixtures were hydrothermally treated in stainless steel capsule at $180^{\circ} \mathrm{C}$ for 5 hours and calcined at $750^{\circ} \mathrm{C}$ for 3 hours. Raw materials, hydrothermally treated and calcined mixtures were analyzed by FTIR, XRD, TGA/DTA and SEM techniques. The reactivity siliceous raw materials towards lime under hydrothermal treatment increase in the following order: sand, metakaolin, dealuminated kaolin. Because sand composes of quartz crystals, metakaolin composes of amorphous metakaolin structure while dealuminated kaolin composes from enriched amorphous silicate. Calcium aluminate and aluminosilicate hydrate were observed in case of metakaolin which contains appreciable amount of $\mathrm{Al}_{2} \mathrm{O}_{3}$. Dicalcium silicate crystallizes into $\beta-\mathrm{C}_{2} \mathrm{~S}$ in the temperature range $590^{\circ} \mathrm{C}-760^{\circ} \mathrm{C}$. Finally, $\beta-\mathrm{C}_{2} \mathrm{~S}$ transforms to $\alpha^{\prime}-\mathrm{C}_{2} \mathrm{~S}$ in the temperature range $790^{\circ} \mathrm{C}-860^{\circ} \mathrm{C}$. There is no sign for the formation of $\gamma-\mathrm{C}_{2} \mathrm{~S}$. This proves that $\mathrm{Ba}^{2+}$ ions stabilized $\beta-\mathrm{C}_{2} \mathrm{~S}$ and retards its transformation to $\gamma-\mathrm{C}_{2} \mathrm{~S}$ because $\mathrm{Ba}^{2+}$ ions replace some of calcium atoms in the structure of $\boldsymbol{\beta}-\mathrm{C}_{2} \mathrm{~S}$.

\section{Keywords}

White Sand, Metakaolin, Dealumiated Kaolin, Hydrothermal Treatment, Calcination

\section{Introduction}

Dicalcium silicate (belite, $\mathrm{C}_{2} \mathrm{~S}$ ) is the major components of Portland cement as same as tricalcium silicate (alite, $\mathrm{C}_{3} \mathrm{~S}$ ) and determines most of the adhesive properties, strength and durability of Portland cement. Belite hydrates 
much slower than alite. Whatever, belite shows about the same physical and mechanical properties as alite after complete hydration [1]. The synthesis of low-energy reactive belite cement is one of the most important challenges. Production of Portland cement consumes much of the fossil fuels (coke, petroleum and natural gas) [2] [3], releasing about $5 \%$ of the total $\mathrm{CO}_{2}$ emission [2] [4] and the whole process needs high temperature for production (i.e. about $1450^{\circ} \mathrm{C}$ ). Recently, $\beta-\mathrm{C}_{2} \mathrm{~S}$ was prepared from different siliceous raw materials such as silica fume, white sand, rice husk ash, silica, amorphous silica, oil well drilling mud and hydraulic dam sludge under various hydrothermal conditions with lime in presence in stabilizer such as $\mathrm{BaCl}_{2}$ or $\mathrm{B}_{2} \mathrm{O}_{3}$ followed by calcination of the product at $650^{\circ} \mathrm{C}-1000^{\circ} \mathrm{C}$ [5]-[9]. The hydrothermal method used by previous researchers for synthesizing belite cement was modified to optimize the synthesis parameters [10] [11]. The hydrothermal treatment temperature was reduced to $100^{\circ} \mathrm{C}$ and atmospheric pressure was used in presence of alkaline $0.6 \mathrm{M} \mathrm{KOH}$ solution using mixture of aluminosilicate waste. The aim of this work is to investigate the influence of silicate structure on the preparation of belite cement from different siliceous raw materials hydrothermally treated with lime and calcined at low temperatures.

\section{Materials and Experimental Techniques}

Lime was produced by calcination of limestone powder (purity > 99\%) in an electrical muffle furnace at $950^{\circ} \mathrm{C}$ for 3 hours. Lime was cooled to room temperature in desiccator, milled and stored in tightly closed plastic bag to avoid carbonation. White sand, metakaolin and dealuminated kaolin were used for preparation of belite. White sand and dealuminated kaolin were provided from Royal cement company, Minia Egypt and Egyptian Shaba company respectively. Metakaolin was prepared from high grade kaolin by calcination in muffle furnace at $750^{\circ} \mathrm{C}$ for 3 hours. Distilled water and analytical grade barium chloride $\left(\mathrm{BaCl}_{2} \cdot 2 \mathrm{H}_{2} \mathrm{O}\right)$ were used without further purification. Mixtures of lime, $\mathrm{BaCl}_{2}$ with white sand, metakaolin or dealuminated $[(\mathrm{Ca}+\mathrm{Ba}) / \mathrm{Si}=2]$ and distilled water (water/solid ratio of 5/1 by weight) placed in stainless steel capsule keeping the occupied volume equals 0.67 of total volume capacity. The capsule was tightly closed, shacked vigorously and hydrothermally treated at $180^{\circ} \mathrm{C}$ for 5 hours in electric oven. The capsule was removed from oven and cooled to room temperature. The hydrothermally treated product was filtered, washed with distilled water, dried in an electric oven and calcined in an electric muffle furnace at $750^{\circ} \mathrm{C}$ for 3 hours. The calcined product was cooled to room temperature in desiccator, milled and stored in tightly closed plastic bags. Mixtures of lime $/ \mathrm{BaCl}_{2} /$ white sand, lime/ $\mathrm{BaCl}_{2} /$ metakaolin and lime/BaCl$/$ dealuminated kaolin were symbolized $\mathrm{S}, \mathrm{M}$ and $\mathrm{D}$ respectively. X-ray diffraction (XRD) analysis were carried out by Philips x-ray diffractometer PW 1370, Co. with Ni filtered $\mathrm{CuK}_{\alpha}$ radiation $(1.5406 \AA)$. The Fourier transform infrared FTIR analysis was measured by spectrometer Perkin Elmer FTIR System Spectrum X in the range $400-4000 \mathrm{~cm}^{-1}$ with spectral resolution of $1 \mathrm{~cm}^{-1}$. Scanning electron microscopy SEM was investigated by Jeol-Dsm 5400 LG apparatus. The thermogravimetric TGA and differential thermogravimetric analyses DTG were carried out with the aid of Shimadzu Corporation thermo analyzer with DTG-60H detector with $10^{\circ} \mathrm{C} / \mathrm{min}$ heating rate from room temperature up to $1000^{\circ} \mathrm{C}$, under nitrogen atmosphere at $40 \mathrm{ml} / \mathrm{min}$ flow rate, the hold time at the appropriate temperature is zero.

\section{Results and Discussion}

Table 1 illustrates the chemical composition of limestone, sand, metakaolin, and dealuminated kaolin determined by XRF. The chemical composition results illustrate that; limestone composes of $\mathrm{CaCO}_{3}$, white sand composes of $\mathrm{SiO}_{2}$ while metakaolin was prepared from high grade kaolin. Dealuminated kaolin has higher $\left(\mathrm{SiO}_{2}\right.$ $+\mathrm{Al}_{2} \mathrm{O}_{3}+\mathrm{Fe}_{2} \mathrm{O}_{3}$ ) content compared to metakaolin and sand.

Figure 1 illustrates the XRD patterns of lime, sand, metakaolin and dealuminated kaolin. Lime composes of calcium oxide $(\mathrm{CaO})$ in addition to small amount of portlandite $\left(\mathrm{Ca}(\mathrm{OH})_{2}\right)$ that arises as a result of partial hydration of lime. White sand composes of quartz $\left(\mathrm{SiO}_{2}\right)$ in addition to small amount of kaolinite $\left(\mathrm{Al}_{2} \mathrm{O}_{3} \cdot 2 \mathrm{SiO}_{2} \cdot 2 \mathrm{H}_{2} \mathrm{O}\right)$. The halo in the range 15 - $352 \theta$, indicated that metakaolin has amorphous structure except that it contains residues of quartz. Dealuminated kaolin has amorphous structure except that it contains residues of quartz, kaolinite and wollastonite $\left(\mathrm{CaO} . \mathrm{SiO}_{2}\right)$. It is evident that studied siliceous materials have not only different content of $\mathrm{SiO}_{2}$ and chemical composition but also different phase composition and crystallinity of $\mathrm{SiO}_{2}$.

Figure 2 illustrates the FTIR spectra of lime, white sand, metakaolin and dealuminated kaolin. In case of lime (Figure 2a), the absorption band at $3640 \mathrm{~cm}^{-1}$ is due to $\mathrm{OH}$-associated with portlandite (hydrated lime). The absorption band at 875 and 1441 are due to the $v^{2}$ and $v^{3}$ of carbonate $\left(\mathrm{CO}_{3}^{2-}\right)$ present as a partial carbonation of 


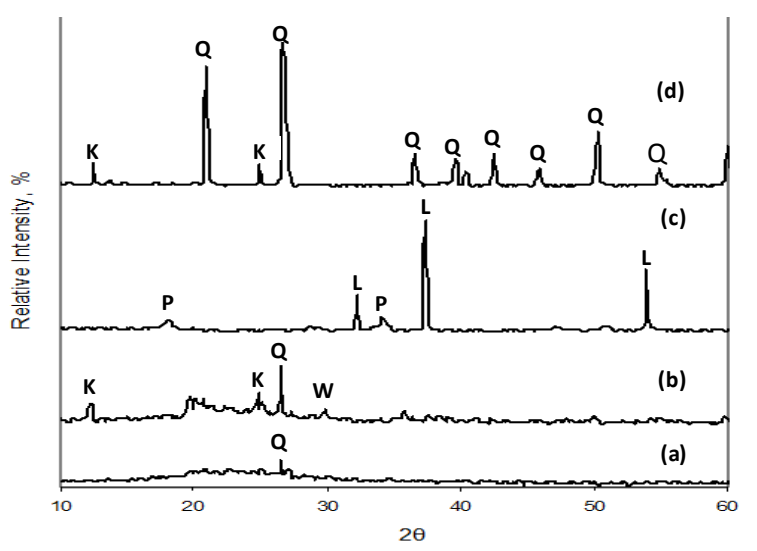

Figure 1. XRD patterns of (a) metakaolin, (b) dealuminated kaolin, (c) lime and (d) white sand (K kaolinite, L lime, P portlandite, Q quartz, W wollastonite).

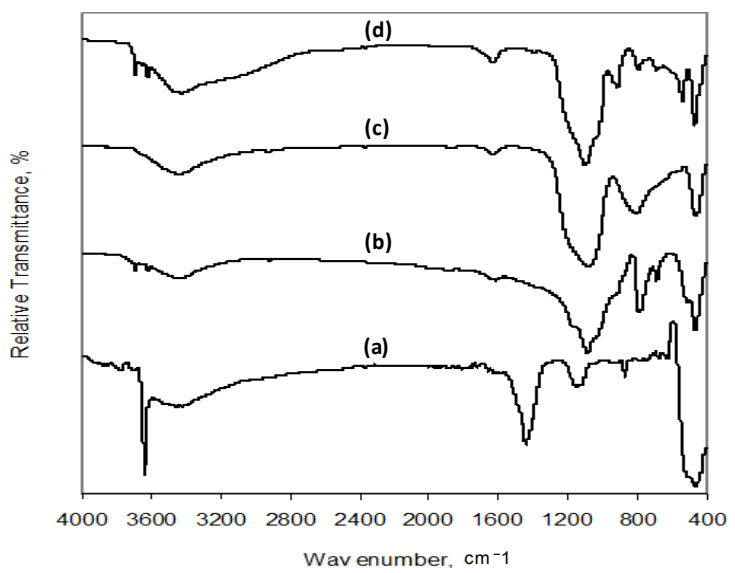

Figure 2. FTIR spectra of (a) lime, (b) white sand, (c) metakaolin and (d) dealuminated kaolin.

Table 1. The chemical composition of limestone, white sand, metakaolin, and dealuminated kaolin determined by XRF.

\begin{tabular}{|c|c|c|c|c|}
\hline Oxide & Limestone & White sand & Metakaolin & Dealuminated kaolin \\
\hline $\mathrm{SiO}_{2}$ & 0.26 & 96.66 & 51.33 & 74.93 \\
\hline $\mathrm{Al}_{2} \mathrm{O}_{3}$ & 0.16 & 2.87 & 42.13 & 9.08 \\
\hline $\mathrm{CaO}$ & 54.59 & 0.14 & 0.57 & 0.00 \\
\hline $\mathrm{Fe}_{2} \mathrm{O}_{3}$ & - & 0.08 & 0.62 & 0.96 \\
\hline $\mathrm{MgO}$ & 0.29 & 0.02 & 0.30 & 0.157 \\
\hline $\mathrm{SO}_{3}$ & 0.05 & - & 0.23 & 1.466 \\
\hline $\mathrm{Na}_{2} \mathrm{O}$ & 0.11 & - & 0.22 & 0.113 \\
\hline $\mathrm{K}_{2} \mathrm{O}$ & 0.03 & - & 0.50 & 0.052 \\
\hline $\mathrm{Cl}^{-}$ & - & - & 0.07 & 0.02 \\
\hline LOI & 43.72 & 1.20 & 2.4 & 9.25 \\
\hline $\mathrm{TiO}_{2}$ & - & - & 0.75 & 3.80 \\
\hline Total & 99.21 & 99.97 & 99.12 & 99.84 \\
\hline \multicolumn{2}{|c|}{$\mathrm{SiO}_{2}+\mathrm{Al}_{2} \mathrm{O}_{3}+\mathrm{Fe}_{2} \mathrm{O}_{3}$} & 99.61 & 94.08 & 84.97 \\
\hline
\end{tabular}


lime [12] [13]. The absorption band at $452 \mathrm{~cm}^{-1}$ is due to Ca-O stretching vibration [14]. In case of white sand, (Figure 2b), the absorption bands at 1084, 795 and $464 \mathrm{~cm}^{-1}$ are corresponding to Si-O-Si asymmetric stretching vibration, Si-O-Si symmetric stretching vibration and O-Si-O bending vibration respectively [15]-[17]. In case of metakaolin (Figure 2c), the band at 1632 and $3444 \mathrm{~cm}^{-1}$ corresponds to bending vibrations of free water molecules adsorbed to amorphous metakaolin surface. The broad band at $807 \mathrm{~cm}^{-1}$ corresponds to Si-O-Al vibrations and is characteristic of the degree of disorder in metakaolin structure [16] [17]. In case of dealuminated kaolin (Figure 2d), the bands at 3694 and $3620 \mathrm{~cm}^{-1}$ corresponds to stretching vibrations of hydroxyl groups which are sitting at the edges of the residual kaolin platelets as well as internal hydroxyl groups. The band at 917 $\mathrm{cm}^{-1}$ corresponds to the Al-O-H bending vibrations (hydroxyl groups sitting on the alumina faces). The band at $693 \mathrm{~cm}^{-1}$ correspond to Si-O-Si symmetric stretching vibration [17]. The band at $542 \mathrm{~cm}^{-1}$ correspond to $\mathrm{Al}^{4+}$-O-Si vibrations, where $\mathrm{Al}^{4+}$ is in octahedral coordination [16].

Figure 3 illustrates the FTIR spectra of S, M and D mixtures hydrothermally treated at $180^{\circ} \mathrm{C}$ for 5 hours. There is a significant change in the shape, position or intensity of the absorption bands at 1084, 795 and 464 $\mathrm{cm}^{-1}$ which are corresponding to Si-O-Si asymmetric stretching, Si-O-Si symmetric stretching and O-Si-O bending vibration respectively. The absorption band at $1084 \mathrm{~cm}^{-1}$ was shifted to lower wavenumber value at $1029 \mathrm{~cm}^{-1}$ whereas the intensity of absorption bands at 794 and $464 \mathrm{~cm}^{-1}$ were significantly reduced. The absorption band at $3449 \mathrm{~cm}^{-1}$ corresponds to vibration of combined water. Silica reacts with lime under hydrothermal conditions and forms dicalcium silicate hydrate. Accordingly, the degree of polymerization of silicate structure is lowered. Absorption bands at $3640,452,875$ and $1441 \mathrm{~cm}^{-1}$ indicate the presence of unreacted lime, i.e. the hydrothermal treatment of the lime/silica mixture $(\mathrm{Ca} / \mathrm{Si}=2 / 1)$ at $180^{\circ} \mathrm{C}$ for 5 hours does not drive the reaction to completion. The absorption band at $3640 \mathrm{~cm}^{-1}$ that corresponds to vibration of $\mathrm{OH}^{-}$groups associated with portlandite was significantly lowered in case of $\mathrm{D}$ mixture. This proves that dealuminated kaolin reacts with higher amount of lime compared to white sand and metakaolin because dealuminated kaolin enriched with amorphous silicate as confirmed by XRD results (Figure $1 \mathrm{~b}$ ).

Figure 4 illustrates the XRD patterns of $\mathrm{S}, \mathrm{M}$ and $\mathrm{D}$ mixtures hydrothermally treated at $180^{\circ} \mathrm{C}$ for 5 hours. The intensity of residual quartz $\mathrm{SiO}_{2}$ and portlandite $\mathrm{Ca}(\mathrm{OH})_{2}$ in hydrothermally treated mixtures decreases in the following descending order; sand $>$ metakaolin $>$ dealuminated kaolin. This indicates that the reactivity of silica rich material towards lime increases in the following ascending order; sand $<$ metakaolin $<$ dealuminated kaolin. Because sand composes of quartz crystals, metakaolin composes of amorphous metakaolin structure while dealuminated kaolin composes from enriched amorphous silicate. At the same time, S mixture show no sign for the existence of dicalcium silicate hydrate due to its amorphous nature. In contrast, $\mathrm{M}$ and D mixtures contain crystalline dicalcium silicate hydrate with lower degree of ordering due to its high content.

Figure 5 illustrates TGA/DTA thermograms of S, M and D mixtures hydrothermally treated at $180^{\circ} \mathrm{C}$ for 5 hours. Result of thermal analysis was illustrated in Table 2. TGA/DTA thermograms illustrated the in situ sequence of thermal reactions and phase transformations that occur when hydrothermally treated mixtures were calcined up to $900^{\circ} \mathrm{C}$. Absorbed water was lost in the temperature range $80^{\circ} \mathrm{C}-130^{\circ} \mathrm{C}$ [18]. Calcium aluminate and aluminosilicate hydrate dehydrates in the temperature range $300^{\circ} \mathrm{C}-350^{\circ} \mathrm{C}$ [19]. Calcium aluminate and

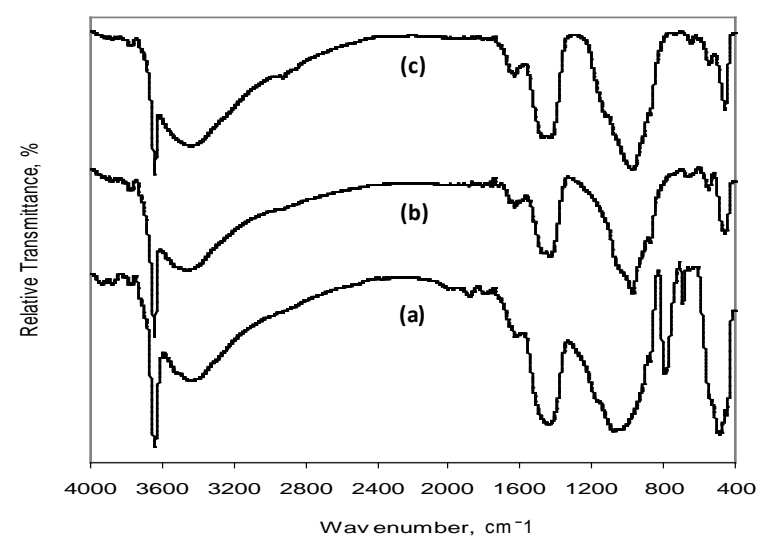

Figure 3. FTIR spectra of (a) S, (b) M and (c) D mixtures hydrothermally treated at $180^{\circ} \mathrm{C}$ for 5 hours. 


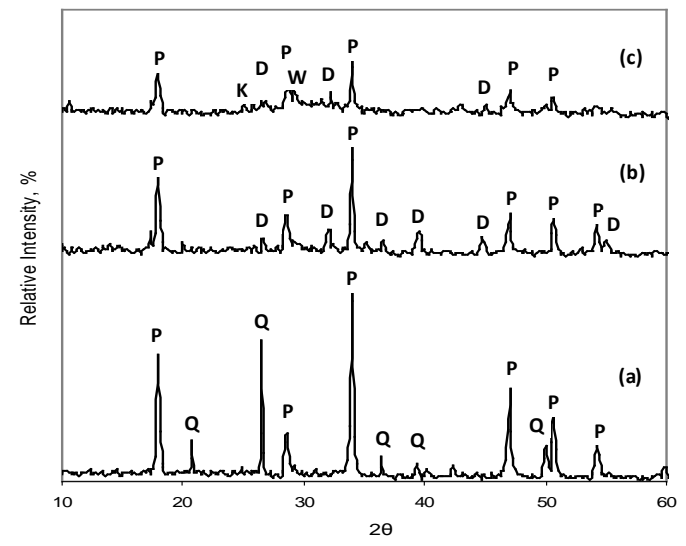

Figure 4. XRD patterns of (a) S, (b) M and (c) D mixtures hydrothermally treated at $180^{\circ} \mathrm{C}$ for 5 hours ( $\mathrm{K}$ kaolinite, $\mathrm{P}$ portlandite, Q quartz, W wollastonite, $\mathrm{D}$ dicalcium silicate hydrate).
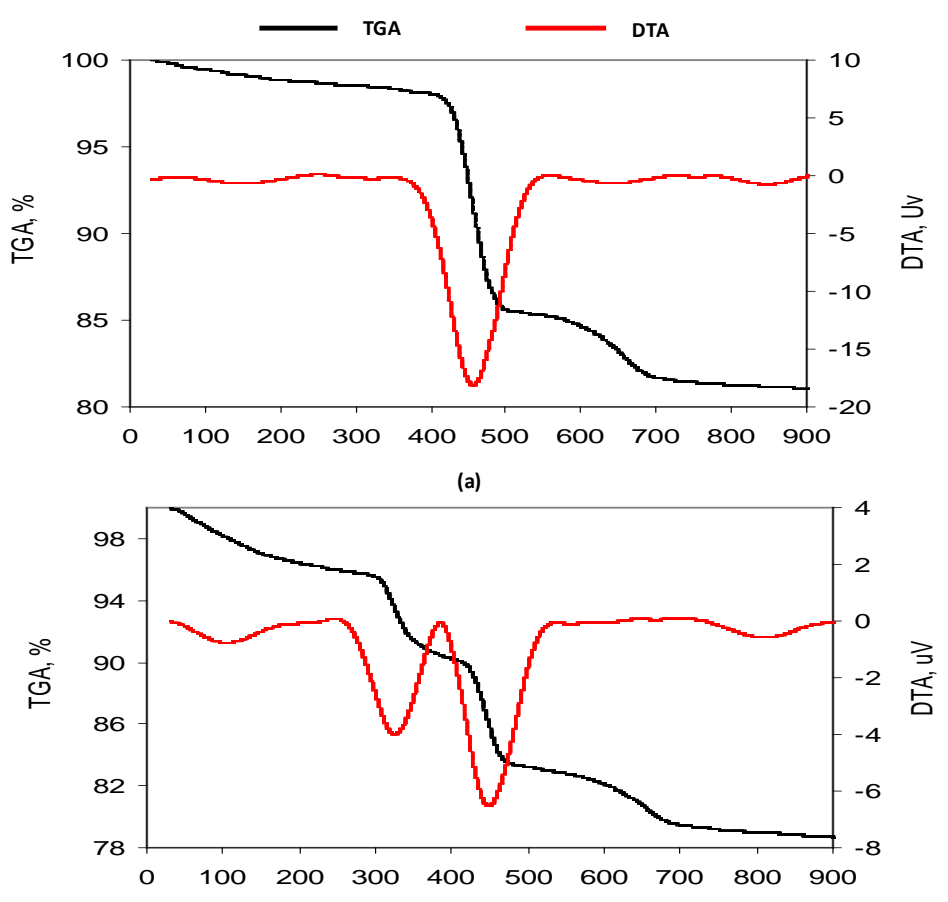

(b)

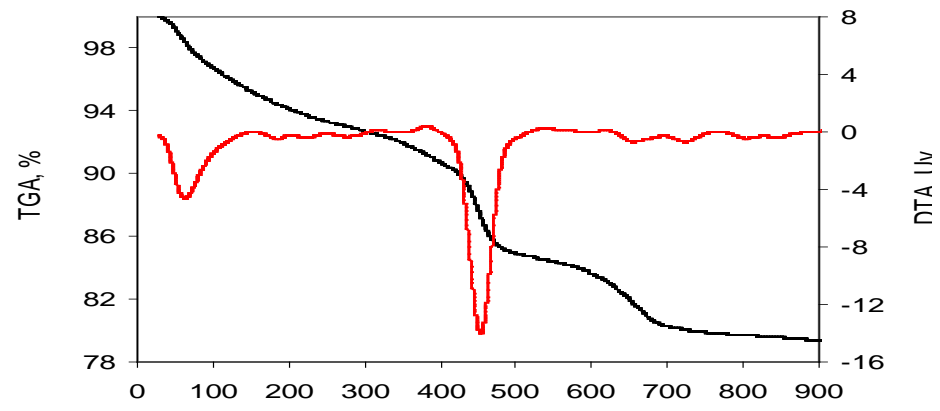

(c)

Temperature, C

Figure 5. TGA and DTA thermograms of (a) S, (b) M and (c) D mixtures hydrothermally treated at $180^{\circ} \mathrm{C}$ for 5 hours. 
Table 2. Result of thermal analysis.

\begin{tabular}{cc}
\hline Phase & Temperature range $\left({ }^{\circ} \mathrm{C}\right)$ \\
\hline Loss of absorbed water & $80-130$ \\
Dehydration of calcium aluminate and aluminosilicate hydrate & $300-350$ \\
Dehydration of residual portlandite & $450-550$ \\
Crystallization of $\beta-\mathrm{C}_{2} \mathrm{~S}$ & $590-760$ \\
$B-\mathrm{C}_{2} \mathrm{~S}$ transformation to $\alpha \cdot-\mathrm{C}_{2} \mathrm{~S}$ & $790-860$ \\
\hline
\end{tabular}

aluminosilicate hydrate only was observed in case of $\mathrm{M}$ mixture because metakaolin contains high amount of $\mathrm{Al}_{2} \mathrm{O}_{3}(42.13 \%)$ in contrast to white sand and dealuminated kaolin as illustrated by XRF analysis. Residual portlandite $\mathrm{Ca}(\mathrm{OH})_{2}$ dehydrates in the temperature range $450^{\circ} \mathrm{C}-550^{\circ} \mathrm{C}$ [20] [21]. Dicalcium silicate crystallizes into $\beta$ - $\mathrm{C}_{2} \mathrm{~S}$ in the temperature range $590^{\circ} \mathrm{C}-760^{\circ} \mathrm{C}$. Finally, $\beta$ - $\mathrm{C}_{2} \mathrm{~S}$ transforms to $\alpha^{\prime}-\mathrm{C}_{2} \mathrm{~S}$ in the temperature range $790^{\circ} \mathrm{C}-860^{\circ} \mathrm{C}$. The relative amount of residual portlandite in hydrothermally treated mixtures which detected from the weight loss in the temperature range $450^{\circ} \mathrm{C}-550^{\circ} \mathrm{C}$ is in the following descending order; sand $>$ metakaolin $>$ dealuminated kaolin. This indicates that the reactivity of silica rich material towards lime increases in the same order as confirmed by FTIR and XRD results.

Figure 6 illustrates the SEM micrographs of S, M and D mixtures hydrothermally treated at $180^{\circ} \mathrm{C}$ for 5 hours. Hydrothermally treated mixtures have different morphologies. S and M mixtures have small cube-like grains whereas D mixture enriched with large grains with rough surfaces. This observation agrees with the following predicted descending order of reactivity; dealuminated kaolin $>$ metakaolin $>$ white sand.

Figure 7 illustrates the FTIR spectra of S, M and D mixtures hydrothermally treated at $180^{\circ} \mathrm{C}$ for 5 hours and calcined at $750^{\circ} \mathrm{C}$ for 3 hours. The absorption band located at $1029 \mathrm{~cm}^{-1}$ was shifted to lower wavenumber value at $955 \mathrm{~cm}^{-1}$ and the absorption bands appearing at 876 and $520 \mathrm{~cm}^{-1}$ are characteristic to $\beta-\mathrm{C}_{2} \mathrm{~S}$ [22]. The absorption bands at 1632 and $3433 \mathrm{~cm}^{-1}$ correspond to bending $\mathrm{H}-\mathrm{O}-\mathrm{H}$ vibration and $\mathrm{O}-\mathrm{H}$ group stretching vibration of adsorbed free water molecules. The absorption bands at 3640 and $1429 \mathrm{~cm}^{-1}$ related to unreacted lime. The absorption band at 781 and $691 \mathrm{~cm}^{-1}$ related to Si-O-Si stretching vibration. Figure 8 illustrates XRD patterns of $\mathrm{S}, \mathrm{M}$ and $\mathrm{D}$ mixtures hydrothermally treated at $180^{\circ} \mathrm{C}$ for 5 hours and calcined at $750^{\circ} \mathrm{C}$ for 3 hours. $\beta-\mathrm{C}_{2} \mathrm{~S}$ formed due to dehydration of dicalcium silicate hydrate. There is no sign for the formation of $\gamma-\mathrm{C}_{2} \mathrm{~S}$. This proves that $\mathrm{Ba}^{2+}$ ions stabilized $\beta$ - $\mathrm{C}_{2} \mathrm{~S}$ and retards its transformation to $\gamma-\mathrm{C}_{2} \mathrm{~S}$ because $\mathrm{Ba}^{2+}$ ions replace some of calcium atoms in the structure of $\beta$ - $\mathrm{C}_{2} \mathrm{~S}$ [23]. Figure 9 illustrates the SEM micrographs of $\mathrm{S}$ and D mixtures hydrothermally treated at $180^{\circ} \mathrm{C}$ for 5 hours and calcined at $750^{\circ} \mathrm{C}$ for 3 hours. It was observed that studied siliceous materials produce belite cement with different microstructure and phase composition as a result of its different $\mathrm{SiO}_{2}$, chemical composition and crystallinity of $\mathrm{SiO}_{2}$.

\section{Conclusions}

The main conclusions of this investigation are:

1) XRF, XRD and FTIR results of white sand, metakaolin and dealuminated kaolin prove that these siliceous materials have different proportions of $\mathrm{SiO}_{2}$ with different phase composition and crystallinity.

2) XRD, FTIR and SEM results of white sand, metakaolin and dealuminated kaolin hydrothermally treated with lime at $180^{\circ} \mathrm{C}$ for 5 hours prove the formation of dicalcium silicate hydrate. Otherwise the hydrothermal treatment does not drive the reaction to completion. It is worth mentioning that dealuminated kaolin reacts with higher amount of lime compared to white sand and metakaolin and then form higher amount of dicalcium silicate hydrate.

3) TGA results give a picture of the thermal decomposition of white sand, metakaolin and dealuminated kaolin hydrothermally treated with lime at $180^{\circ} \mathrm{C}$ for 5 hours. TGA results prove that $\beta$ - $\mathrm{C}_{2} \mathrm{~S}$ crystallizes in the temperature range $590^{\circ} \mathrm{C}-760^{\circ} \mathrm{C}$ and transforms to $\alpha^{\prime}-\mathrm{C}_{2} \mathrm{~S}$ in the temperature range $790^{\circ} \mathrm{C}-860^{\circ} \mathrm{C}$.

4) XRD, FTIR and SEM results of white sand, metakaolin and dealuminated kaolin hydrothermally treated with lime at $180^{\circ} \mathrm{C}$ for 5 hours and calcined at $750^{\circ} \mathrm{C}$ for 3 hours prove the formation of $\beta-\mathrm{C}_{2} \mathrm{~S}$. $\mathrm{Ba}^{2+}$ ions stabilized $\beta-\mathrm{C}_{2} \mathrm{~S}$ and retarded its transformation to $\gamma-\mathrm{C}_{2} \mathrm{~S}$.

5) The silicate anion structure greatly affects the reactivity of siliceous raw materials towards lime under hy 

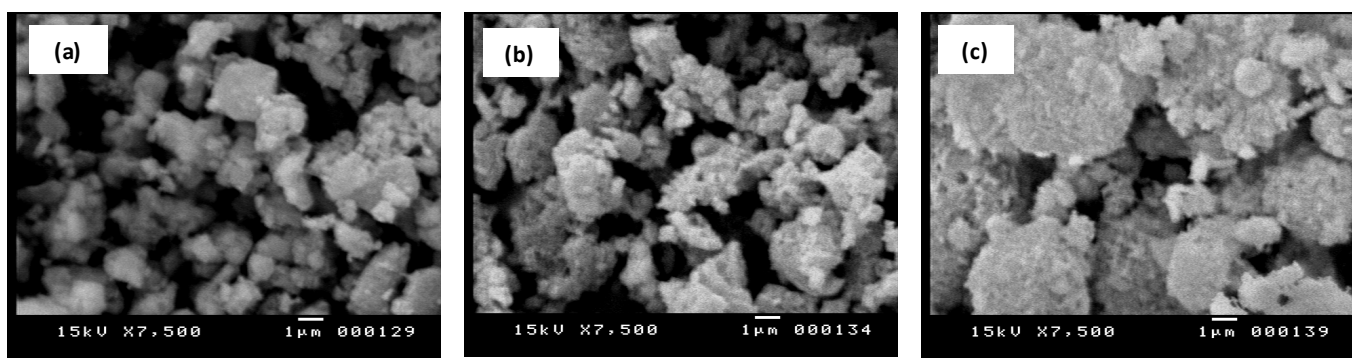

Figure 6. SEM micrographs of (a) S, (b) M and (c) D mixtures hydrothermally treated at $180^{\circ} \mathrm{C}$ for 5 hours.

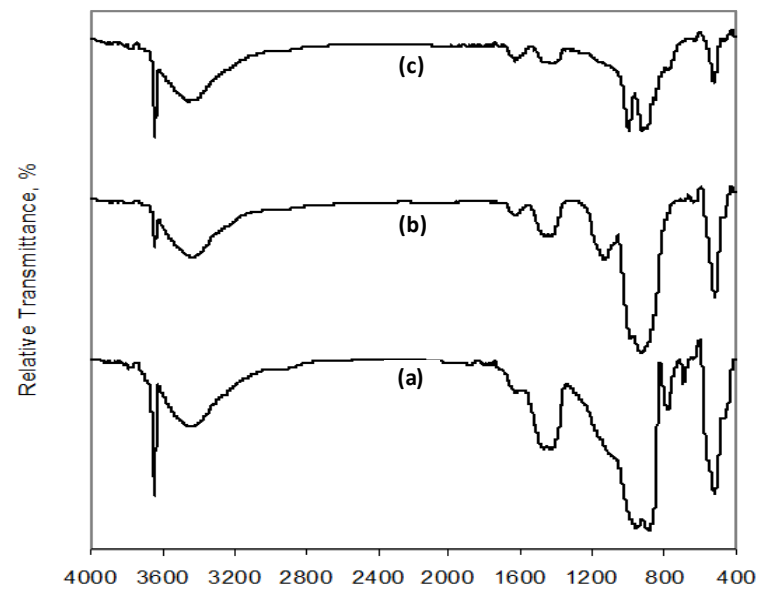

Wav enum ber, $\mathrm{cm}^{-1}$

Figure 7. FTIR spectra of (a) S, (b) M and (c) D mixtures hydrothermally treated at $180^{\circ} \mathrm{C}$ for 5 hours and calcined at $750^{\circ} \mathrm{C}$ for 3 hours.

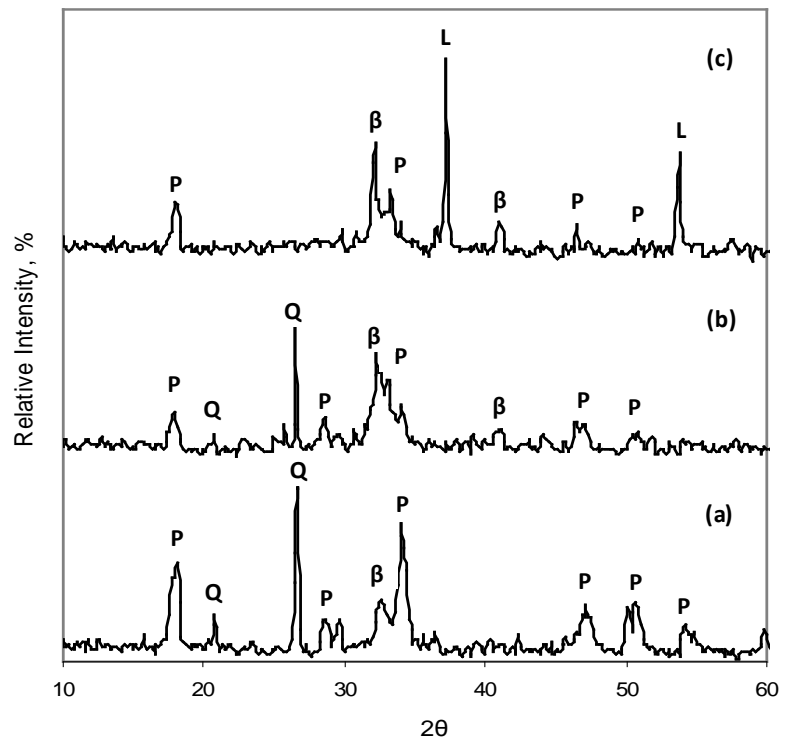

Figure 8. XRD patterns of (a) S, (b) M and (c) D mixtures hydrothermally treated at $180^{\circ} \mathrm{C}$ for 5 hours and calcined at $750^{\circ} \mathrm{C}$ for 3 hours (P: portlandite, Q: quartz, $\beta$ : belite, L: lime).

drothermal treatment. Dealuminated kaolin is more reactive compared to sand and metakaolin because of its amorphous silicate structure.

6) Based on current results, new studies in the future must be conducted to clarify the parameters which affect 

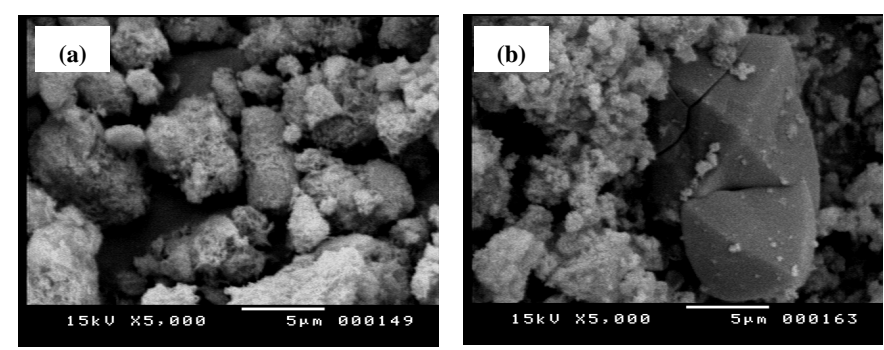

Figure 9. SEM micrographs of (a) S and (b) D mixtures hydrothermally treated at $180^{\circ} \mathrm{C}$ for 5 hours and calcined at $750^{\circ} \mathrm{C}$ for 3 hours.

the reactivity of siliceous raw materials under hydrothermal treatment with lime in order to prepare low temperature belite cement.

\section{References}

[1] Young, J.F. and Mindess, S. (1981) Concrete. Prentice-Hall, New Jersey.

[2] European Commission (2010) Reference Document on Best Available Techniques in Cement, Lime and Magnesium Oxide Manufacturing Industries. ftp://ftp.jrc.es/pub/eippcb/doc/clm_bref_0510.pdf.

[3] Johansen, V. and Kouznetsova, T.V. (1992) Clinker Formation and New Processes. 9th Int cong chem cem, 49.

[4] Van Oss, H. and Padovani, A.C. (2003) Cement Manufacture and the Environment, Part II: Environmental Challenges and Opportunities. Journal of Industrial Ecology, 7, 93. http://dx.doi.org/10.1162/108819803766729212

[5] Tantawy, M.A., Shatat, M.R., El-Roudi, A.M., Taher, M.A. and Abd-El-Hamed, M. (2012) Low Temperature Synthesis of Belite Cement Based on Silica Fume and Lime. International Scholarly Research Notices, 2014, Article ID: 873215.

[6] Tantawy, M.A. (2014) Low Temperature Synthesis of Belite Cement from White Sand and Lime. Int J Eng Res Tech, 3, 1351.

[7] Singh, N.B. (2006) Hydrothermal Synthesis of $\beta$-Dicalcium Silicate $\left(\beta-\mathrm{Ca}_{2} \mathrm{SiO}_{4}\right)$. Progress in Crystal Growth and Characterization of Materials, 52, 77-83. http://dx.doi.org/10.1016/j.pcrysgrow.2006.03.011

[8] Georgescu, M., Tipan, J., Badanoiu, A., Crisan, D. and Dragan, I. (2000) Highly Reactive Dicalcium Silicate Synthesised by Hydrothermal Processing. Cement and Concrete Composites, 22, 315. http://dx.doi.org/10.1016/S0958-9465(00)00017-2

[9] Rodrigues, F.A. and Monteiro, P.J.M. (1999) Hydrothermal Synthesis of Cements from Rice Hull Ash. Journal of Materials Science Letters, 18, 1551. http://dx.doi.org/10.1023/A:1006639711393

[10] Kacimi, L., Cyr, M. and Clastres, P. (2010) Synthesis of $\alpha^{\prime}{ }_{\mathrm{L}}-\mathrm{C}_{2} \mathrm{~S}$ Cement from Fly-Ash Using the Hydrothermal Method at Low Temperature and Atmospheric Pressure. Journal of Hazardous Materials, 181, 593. http://dx.doi.org/10.1016/j.jhazmat.2010.05.054

[11] Mazouzi, W., Kacimi, L., Cyr, M. and Clastres, P. (2014) Properties of Low Temperature Belite Cements Made from Aluminosilicate Wastes by Hydrothermal Method. Cement and Concrete Composites, 53, 170-177. http://dx.doi.org/10.1016/j.cemconcomp.2014.07.001

[12] Shen, Y.H., Li, C.H., Zhu, X.M., Xie, A.J., Qiu, L.G. and Zhu, J.M. (2007) Study on the Preparation and Formation Mechanism of Barium Sulphate Nanoparticles Modified by Different Organic Acids. Journal of Chemical Sciences, 119, 319-324. http://dx.doi.org/10.1007/s12039-007-0043-3

[13] Gupta, A., Singh, P. and Shivakumara, C. (2010) Synthesis of $\mathrm{BaSO}_{4}$ Nanoparticles by Precipitation Method Using Sodium Hexametaphosphate as a Stabilizer. Solid State Communications, 150, 386-388. http://dx.doi.org/10.1016/j.ssc.2009.11.039

[14] Rodrigues, F.A. (1999) Synthesis of Cements from Rice Hull. Symposia Papers Presented before the Division of Environmental Chemistry, American Chemical Society, New Orleans, Vol. 39, 30-31.

[15] Baltakys, K., Jauberthie, R., Siauciunas, R. and Kaminskas, R. (2007) Influence of Modification of $\mathrm{SiO}_{2}$ on the Formation of Calcium Silicate Hydrate. J Mater Sci Pol, 25, 663.

[16] Liew, Y.M., Kamarudin, H., Mustafa Al Bakri, A.M., Luqman, M., Khairul Nizar, I., Ruzaidi, C.M. and Heah, C.Y. (2012) Processing and Characterization of Calcined Kaolin Cement Powder. Construction and Building Materials, 30, 794-802. http://dx.doi.org/10.1016/j.conbuildmat.2011.12.079 
[17] Galan, E., Aparicio, P., Miras, A., Michailidis, K. and Tsirambides, A. (1996) Technical Properties of Compounded Kaolin Sample from Griva (Macedonia, Greece). Applied Clay Science, 10, 477-490. http://dx.doi.org/10.1016/0169-1317(95)00041-0

[18] Garbev, K. (2004) Structure, Properties and Quantitative Rietveld Analysis of Calcium Silicate Hydrates (C-S-H Phases) Crystallised under Hydrothermal Conditions, Ph.D. Thesis, Institut fur Technische Chemie von der Fakultat fur Chemie und Geowissenschaften der Ruprecht-Karls-Universitat Hiedelberg, Germany.

[19] Taylor, H.F.W. (1998) Cement Chemistry. 2th Edition, Thomas Telford Publication, London.

[20] Lea, F.M. (1998) The Chemistry of Cement and Concrete. In: Hewlett, P.C., Ed., 4th Edition, Edward Arnold, London.

[21] Heikal, M., El-Didamony, H. and Morsy, M.S. (2000) Limestone-Filled Pozzolanic Cement. Cement and Concrete Research, 30, 1827-1834. http://dx.doi.org/10.1016/S0008-8846(00)00402-6

[22] Fernandez, L., Alonso, C., Hidalgo, A. and Andrade, C. (2005) The Role of Magnesium during the Hydration of C3S and C-S-H Formation. Scanning Electron Microscopy and Mid-Infrared Studies. Advances in Cement Research, 17, 921. http://dx.doi.org/10.1680/adcr.2005.17.1.9

[23] Chan, C.J., Kriven, W.M. and Francis Young, J. (1992) Physical Stabilization of the $\beta-\gamma$ Transformation in Dicalcium Silicate. Journal of the American Ceramic Society, 75, 1621-1627.

http://dx.doi.org/10.1111/j.1151-2916.1992.tb04234.x 